\title{
Incidence and outcome of salvage cystectomy after bladder sparing therapy for muscle invasive bladder cancer: a systematic review and meta-analysis
}

\author{
Victor M. Schuettfort ${ }^{1,2}$ - Benjamin Pradere ${ }^{1,3} \cdot$ Fahad Quhal $^{1,4} \cdot$ Hadi Mostafaei $^{1,5} \cdot$ Ekaterina Laukhtina $^{1,6}$. \\ Keiichiro Mori ${ }^{1,7} \cdot$ Reza Sari Motlagh $^{1} \cdot$ Margit Fisch $^{2} \cdot$ David D'Andrea $^{1} \cdot$ Michael Rink $^{2} \cdot$ Paolo Gontero $^{8}$. \\ Francesco Soria $^{8}$. Shahrokh F. Shariat ${ }^{1,6,9,10,11,12}$
}

Received: 13 July 2020 / Accepted: 31 August 2020 / Published online: 29 September 2020

(c) The Author(s) 2020

\begin{abstract}
Objective We conducted a systematic review and meta-analysis to assess the available literature regarding the surgical and oncologic outcomes of patients undergoing salvage radical cystectomy (SV-RC) for recurrence or failure of bladder sparing therapy (BST) for muscle-invasive bladder cancer (MIBC).

Methods We searched MEDLINE (PubMed), EMBASE and Google Scholar databases in May 2020. We included all studies of patients with $\geq \mathrm{cT} 2 \mathrm{~N} 0 / \mathrm{xM} 0$ bladder cancer that were eligible for all treatment modalities at the time of treatment decision who underwent BST including radiotherapy (RTX). A meta-analysis was conducted to calculate the pooled rate of several variables associated with an increased need for SV-RC. Study quality and risk of bias were assessed using MINORS criteria. Results 73 studies comprising 9110 patients were eligible for the meta-analysis. Weighted mean follow-up time was 61.1 months (range 12-144). The pooled rate of non-response to BST and local recurrence after BST, the two primary reasons for SV-RC, was $15.5 \%$ and $28.7 \%$, respectively. The pooled rate of SV-RC was $19.2 \%$ for studies with a follow-up longer than 5 years. Only three studies provided a thorough report of complication rates after SV-RC. The overall complication rate ranged between 67 and $72 \%$ with a 30-day mortality rate of $0-8.8 \%$. The pooled rates of 5 and 10 -year disease-free survival after SV-RC were $54.3 \%$ and $45.6 \%$, respectively.

Conclusion Approximately one-fifth of patients treated with BST with a curative intent eventually require SV-RC. This procedure carries a proportionally high rate of complications and is usually accompanied by an incontinent urinary diversion.
\end{abstract}

Keywords MIBC $\cdot$ Bladder sparing treatment $\cdot$ Bladder $\cdot$ Cancer $\cdot$ Salvage cystectomy $\cdot$ Radiotherapy

\section{Introduction}

Data from large meta-analyses suggest that bladder sparing therapy (BST) could offer equal oncologic outcomes compared to radical cystectomy (RC) in well-selected patients with muscle-invasive bladder cancer (MIBC) [1-3]. The most effective BST strategy consists of maximal transurethral resection of bladder tumor (TURBT) followed by

Electronic supplementary material The online version of this article (https://doi.org/10.1007/s00345-020-03436-0) contains supplementary material, which is available to authorized users.

Shahrokh F. Shariat

shahrokh.shariat@meduniwien.ac.at

Extended author information available on the last page of the article radiochemotherapy (RCT) [4]. This treatment strategy was primarily used for the elderly, frail patients who were ineligible for RC [5-7]. Nowadays, multiple guidelines support the use of BST in the form of a trimodal therapy (TMT) as an alternative to primary RC with curative intent for selected, well-informed and compliant patients, who desire to retain their bladder [4, 8-10]. Despite the failure of all randomized controlled trials due to accrual (e.g. NCT 02716896 and SPARE [11]), the oncological efficacy of TMT seems noninferior to primary RC in well-selected patients [1-6].

Patients usually would prefer a BST, as it is considered tolerable due to its minimal invasiveness with genuinely manageable toxicity $[12,13]$. However, a significant proportion of patients may eventually need a salvage radical cystectomy (SV-RC) due to non-response to BST or local recurrence [14-16]. For an alternative therapy to be embraced, 
it needs to also ensure that in addition to a low failure rate, the unfortunate cases can be salvaged with minimal adverse events. However, irradiated tissues are usually more fragile and difficult to dissect, leading to an increased risk of complications following SV-RC [17-21]. In addition, the quality of life after SV-RC may not be similar to primary RC, as the optimal patient for TMT has a unifocal cT2 tumor that is fully resectable without carcinoma in situ or hydronephrosis [4]. Patients fulfilling these criteria could also be candidates for a high class, nerve-sparing primary RC with continent urinary diversion.

We, therefore, conducted a systematic review to evaluate the surgical and oncologic outcomes following SV-RC after BST with a curative intent. We also performed a metaanalysis to investigate the pooled incidence rate of SV-RC and assessed the variables associated with an increased likelihood of requirement for SV-RC.

\section{Methods}

\section{Search strategy for identification of studies}

This meta-analysis was carried out based on the guidelines of the Preferred Reporting Items for Meta-Analyses of Observational Studies in Epidemiology Statement and registered on PROSPERO (ID: CRD42020187685) [22]. In May 2020, a literature search on MEDLINE (PubMed), EMBASE and Google Scholar databases was performed using a Boolean operator and the keywords: salvage cystectomy, rescue surgery, radiotherapy, trimodal therapy, bladder sparing therapy, multimodal therapy, bladder preservation, radiotherapy, radiochemotherapy, pelvic radiation and muscle invasive bladder cancer. Additionally, reference lists of the retrieved articles were analyzed to identify further studies. Studies lacking original patient data, abstracts, and non-English articles were excluded. The primary outcome of interest was the pooled rate of SV-RC, as well as the surgical and oncologic outcomes of patients treated with SV-RC for BST failure. Secondary outcomes of interest were variables associated with a previously reported increased likelihood for SV-RC [23].

\section{Inclusion criteria}

We included all studies of patients with $\geq \mathrm{cT} 2 \mathrm{~N} 0 / \mathrm{xM} 0$ bladder cancer who underwent BST which included radiotherapy (RTX). Patients had to be eligible for all treatment modalities at the time of first-line treatment decision. The choice of treatment modality was usually based on patients and/or physicians' preferences as well as participation in clinical trials. Studies that focused explicitly on elderly patients or patients unfit for surgery (at time of BST) were excluded, as there are limited treatment options for these patients and SV-RC will frequently not be feasible despite being otherwise required. To focus on modern surgical and radiation treatment, we only included studies published between January 2000 and May 2020. To analyze a homogeneous cohort, we excluded studies that focused on primary partial cystectomy or lymph node dissection (LND), brachytherapy or only TURBT/chemotherapy as part of BST. Studies reporting the outcome of SV-RC following pelvic radiotherapy for non-bladder cancer malignancies were excluded. Patient cohorts that focused on pure variants of urothelial carcinoma were also excluded, as there is little data on the value of BST in these patients. Studies reporting results of mixed cohorts were included. Repeated publications from the same authors or institutions were excluded, except for publications with updated or new data from the same institution.

\section{Data extraction}

Data were extracted independently by two authors. Titles and abstracts were screened to determine whether they met inclusion criteria. Full-text publications of all studies not primarily excluded were obtained and reviewed to check eligibility. If rates were not reported, they were calculated using the number of included patients as denominator, whenever it was possible. Non-response to BST was defined as a stable or progressive disease within 6 months after the initial treatment. Perioperative complications were defined as any complications within 30 days of SV-RC. Early SV-RC was defined as a SV-RC within 6 months of BST. Local recurrence was defined as intravesical recurrence. Missing data were obtained by contacting the authors of the relevant studies, if needed. All discrepancies regarding data extraction were resolved by consensus with co-investigators.

\section{Quality assessment}

As the vast majority of included studies were non-randomized interventional studies, assessment of study quality and risk of bias was performed using the methodological index for non-randomized studies (MINORS) criteria [24]. MINORS is a validated tool, which consist of eight different items for the quality assessment of non-comparative studies. A high risk of bias was attributed for studies with less than 12 points.

\section{Statistical analysis}

If sufficient data were available for evaluation, a meta-analysis of proportions was conducted to calculate the weighted summary overall proportion. These pooled rates represent the average from multiple studies weighted by the inverse of their sampling variances and are presented along with $95 \%$ 
confidence intervals (95\% CI) calculated using a normal approximation [25]. The proportion of interest was re-calculated from the relevant numerator (event) and denominator (total cases), if possible. Depending on the distribution of proportions, either no or logistic transformation was applied [25]. When significant heterogeneity ( $p$ value of $<0.05$ in the Cochrane $Q$ test and $I^{2}>50 \%$ ) was observed, a randomeffects model (DerSimonian and Laird) was applied. The predominantly small sample sizes and retrospective study design prevented multivariable meta-regression due to inability to properly adjust for the effects of confounders. As it has been shown to be problematic in meta-analyses of proportions, assessment of publication bias using funnel plots was not performed [26]. All analyses were conducted using R Studio, Version 3.6.3.

\section{Results}

Overall, we identified 73 studies comprising 9110 patients who underwent primary BST with curative intent according to our inclusion criteria (Fig. 1). The characteristics of
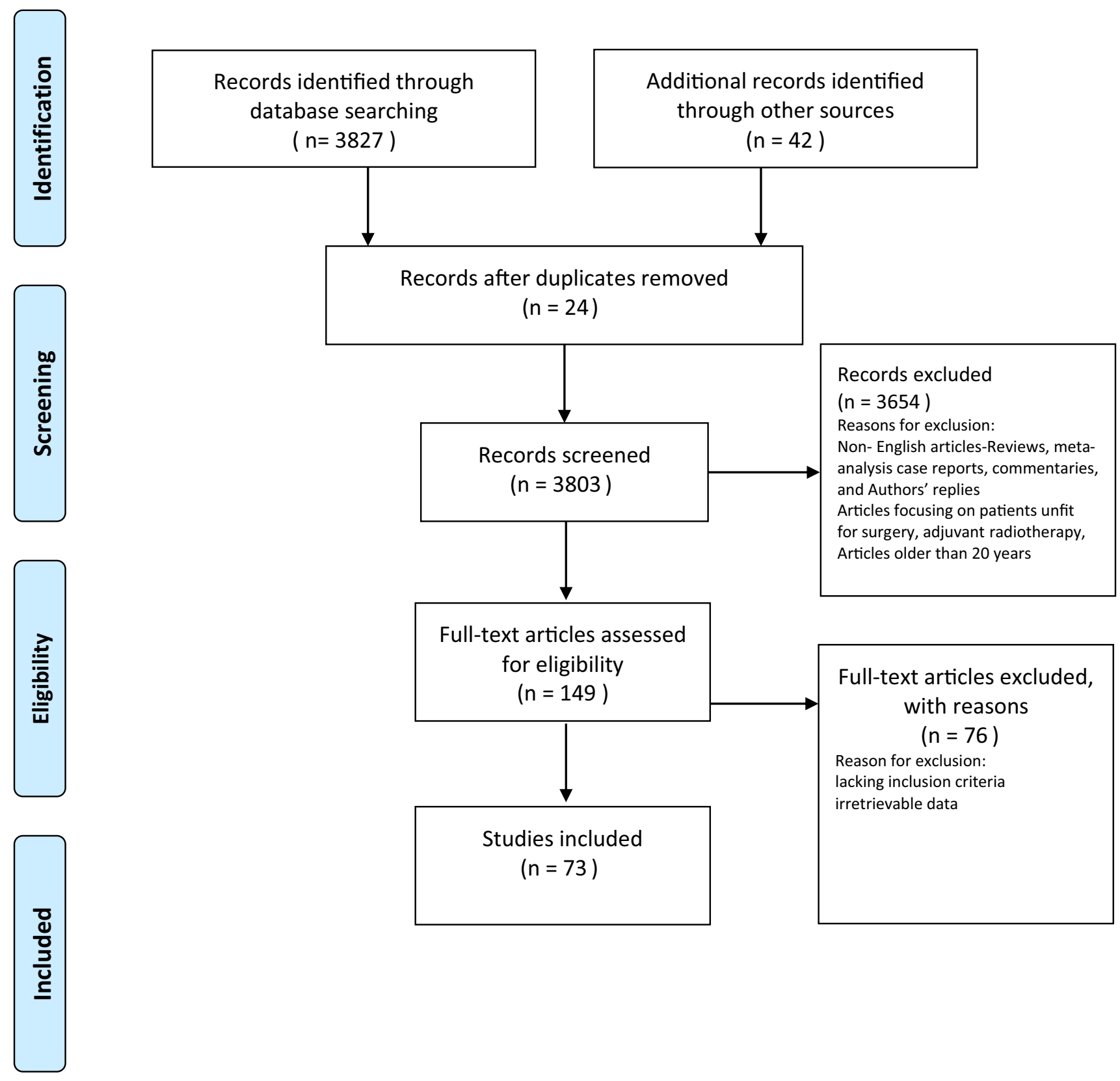

Fig. 1 Flow diagram of the study selection procedure for the systematic review and meta-analysis 
included patients and the applied study methodology are shown in Supplementary Table 1 [58-118]. Weighted mean follow-up time was 61.1 months (range 12-144 months).

\section{Pooled rate of salvage radical cystectomy}

The pooled rate of all subsequently necessary SV-RC was $15.5 \%$ (95\% CI $13.0-18.0, I^{2}=91 \%$, Fig. 2). If only studies with a follow-up longer than 5 years were included, this rate rose to $19.2 \%$ (95\% CI $15.4-23.0, I^{2}=92 \%$ ).
The proportion of early and late SV-RC was equally balanced $(55.7 \%$ vs. $44.3 \%)$. Pooled rate of incontinent urinary diversion was $91.1 \%$ for all reported cases $(95 \%$ CI 76.1-97.0, $I^{2}=68 \%$, logistic transformation applied). In the series of Chahal et al. which compared the outcome of SV-RC and primary RC, $8.3 \%$ in the primary RC group had a continent urinary diversion vs. only $3.5 \%$ in the SV-RC group. The pooled rate of 5- and 10-year DFS after SV-RC was $54.3 \%\left(95 \%\right.$ CI $\left.48.6-60.1, I^{2}=79 \%\right)$ and $45.6 \%$ (95\% CI 41.6-49.6, $I^{2}=0 \%$, fixed effect model), respectively.
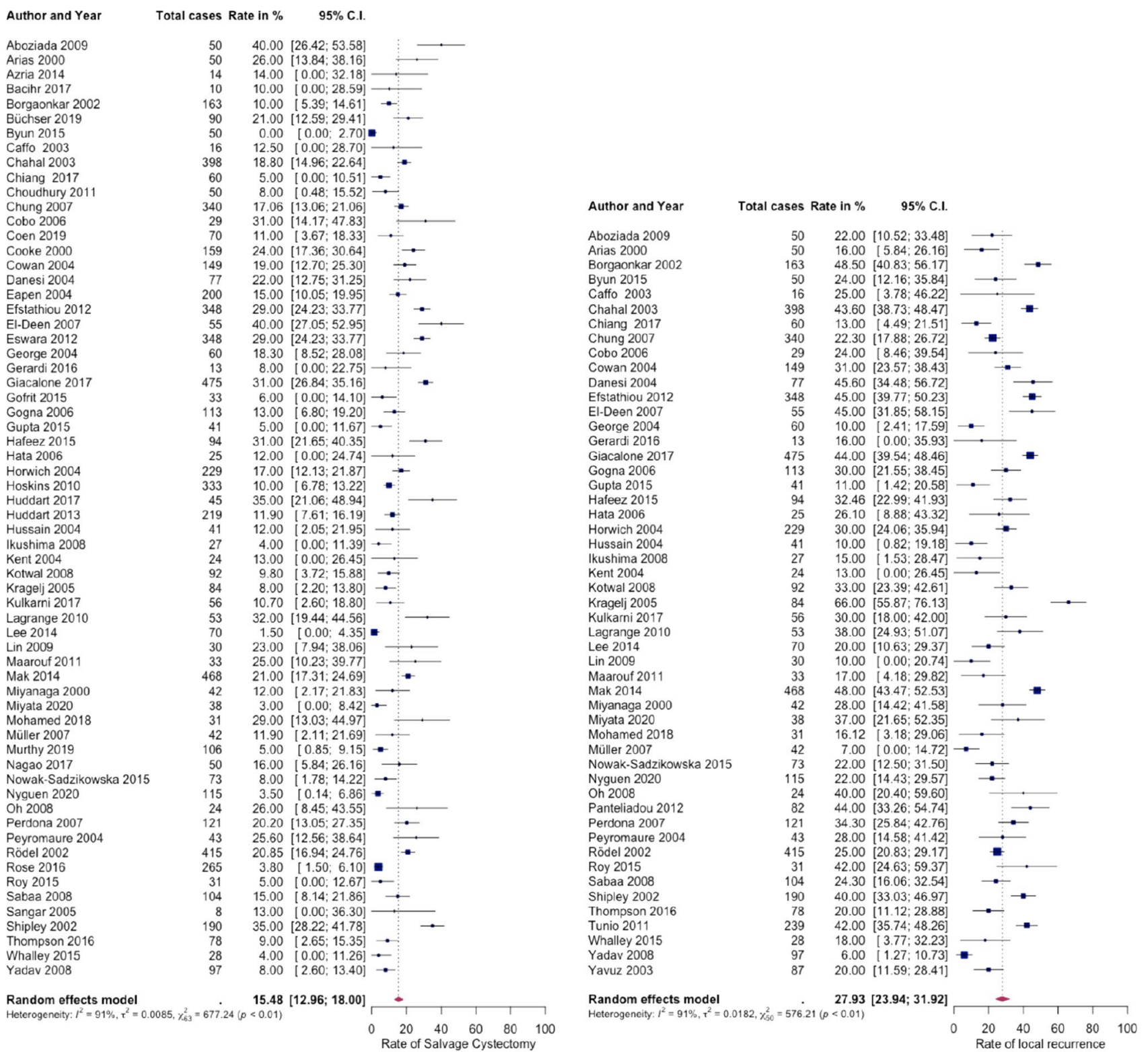

Fig. 2 Forest plots showing the pooled rates of salvage cystectomy (left) and local recurrence (right) for studies following bladder sparing treatment of muscle-invasive bladder cancer 


\section{Complications rates of SV-RC}

Only three studies provided a thorough report of complications after SV-RC, while two further studies provided partial reports. Of these, four studies reported the overall complication rate, which ranged between 67 and 72.2\% [27-30]. Two study groups found that the overall complication rates were not significantly worse for SV-RC and primary RC (Chahal et al. [29]: $75 \%$ vs $71.4 \%$, Iwai et al. [28]: $67 \%$ vs. $57 \%$ ). The rate of major complications was found to be higher following SV-RC compared to primary RC ( $22 \%$ vs. $12 \%$ ) [28]. Chahal et al. reported that the perioperative complications rate was lower for primary RC in comparison to SV-RC (37\% vs $47.1 \%$ ) [29]. With respect to specific complications, Iwai et al. report a higher rate of overall urinary anastomosisrelated complications $(11 \%$ vs. $2 \%, p=0.007)$ and major gastrointestinal complications $(14 \%$ vs. $4 \%, p=0.02)$ in SV-RC vs. primary RC patients [28]. Similar, Chahal et al. reported a higher rate of bowel leakage following SV-RC, in comparison to patients treated with primary $\mathrm{RC}(8.7 \%$ vs 3\%) [29].

30-day mortality rates for SV-RC-treated patients were generally low (Supplementary Table 2), but were higher than those for primary RC (30 day mortality $8.8 \%$ vs $3.1 \%$; 3-month mortality: $19.2 \%$ vs $14.5 \%$ ) [29]. Compared to primary RC, SV-RC, therefore, seems to be associated with an increased risk of both complications and perioperative mortality.

\section{Variables associated with an increased rate of SV-RC}

No study focused on analyzing variables that could predict the need for SV-RC. Less than $2 \%$ of the patients underwent SV-RC due to non-oncologic reasons [14, 15, 31, 32]. Local recurrence and non-response to BST were found to be the primary reasons for SV-RC. Pooled rate of local recurrence was $27.9 \%$ (95\% CI $23.9-31.9, I^{2}=92 \%$ ), this increased to $32.9 \%$ for studies with longer than 5 years follow-up (95\% CI $27.0-38.7, I^{2}=91 \%$, Fig. 2). In our study, pooled rate of complete response to BST was $75.1 \%$ (95\% CI 70.8-79.4, $I^{2}=95 \%$ ), while pooled rate for non-response (stable or progressive disease) was $15.5 \%$ (95\% CI 11.9-19.0, $I^{2}=93 \%$ ). Several studies reported that a significant proportion of patients were not salvageable after BST treatment failure $(12-52 \%)[14,33,34]$.

Two large series noted that in patients with an incomplete primary TURBT before BST, the rate of SV-RC was higher compared to the rest of the cohort (e.g. $42 \%$ vs. $22 \%$ ) [32, 35]. In our study, weighted pooled rate of incomplete TURBT before BST was 38.6\% (95\% CI 27.9-49.3, $\left.I^{2}=99 \%\right)$. Patients undergoing SV-RC had a higher proportion of cT3 and cT4 diseases compared to those who did not need a SV-RC (43\% vs. $30 \%, p=0.007)$ [35].

\section{Quality assessment}

In terms of methodologic quality, MINORS scores ranged from 7 to 16 (mean 12.7, median 12). Overall, 80.8\% (59/73) of all studies included into the meta-analysis were, therefore, found to be without a risk of bias.

\section{Discussion}

The prerequisite criteria for BST to be considered as an adequate alternative to primary RC in patients with MIBC need to be addressed. It is obvious that the equivalence of BST to primary RC, the standard of care in this disease space, can only be assessed in a prospective randomized controlled clinical trial. Since such a study is nearly impossible, due to the patients and physicians' lack of enthusiasm, we have attempted to investigate the criteria that would allow BST to be accepted as an alternative to primary RC (i.e. low failure rates and a salvage strategy after treatment failure that offers an acceptable morbidity and mortality). We found that one in five patients treated with primary BST with a curative intent subsequently required SV-RC. However, these patients may have represented only a proportion of failures, as not all patients will be eligible for SV-RC. Failure of BST and subsequent time delay might deprive patients of other treatments alternatives [14, 33, 34]. Nevertheless, reported bladder preservation rates of $70-85 \%$ seem to be encouraging, especially as further developments in BST, like a tretramodale approach or immunotherapy, might improve treatment outcomes and subsequently reduce the likelihood of subsequent SV-RC [36].

Despite the significant rate of failure in BST leading to subsequent SV-RC, only 3 out of 73 studies thoroughly reported the outcomes of SV-RC. Even with advances in intra- and perioperative care, SV-RC remains a challenging surgery. Indeed, it leads to overall complication rates ranging between 67 and 72\% [27-30]. If standardized definitions are applied and a meticulous workup of all complications is performed, these rates are very likely to increase even more [37]. While a non-randomized comparison is not without bias, modern primary RC shows much lower complication rates $[38,39]$. Mortality rates of SV-RC were found to be low in our systematic review, but still data suggest worse early and 3 months survival rates following SV-RC in comparison to primary RC [29, 40, 41]. Patients undergoing SV-RC lose their opportunity for a high-quality primary $\mathrm{RC}$ (i.e. nerve sparing with a continent urinary diversion). While it still remains unclear if one form urinary diversion is superior to another in terms of quality of life, it is believed that most patients will favor a continent urinary diversion [42]. SV-RC, however, usually entails an incontinent urinary diversion due to irradiation damage to the pelvic tissue. 
Even though we did not find any data on the use of nervesparing SV-RC, it seems unlikely that this is possible, let alone be successful. While a successful BST seems to have little effect on quality of life, a non-nerve sparing approach and an incontinent urinary diversion following SV-RC may potentially decrease the quality of life after failure of BST [43]. This needs to be addressed in the counselling of MIBC patients regarding the risks, benefits and alternatives to primary RC. Patients also need to be counselled on the high local recurrence rate following BST, which necessitates a lifelong follow-up and further invasive procedures, thus increasing morbidity and health care costs [44-46].

Predictors of SV-RC need to be investigated to improve patient selection. In agreement with the literature on oncologic outcome after BST, our findings suggest that patients with multifocal tumors, hydronephrosis non-organ confined disease, incomplete TURBT or carcinoma in situ should not be selected for BST [12]. Despite intensified research, there is a persistent lack of clinical useful biomarkers for patient selection, as all reported results are still exploratory [47-53]. So far, as seen in patients undergoing primary RC, there remains a substantial risk for understaging even in patients seemingly ideal for BST [54-56]. As LND remains the most accurate method for complete pathological staging and thus for detection of more aggressive tumors while simultaneously treating micrometastases, neoadjuvant chemotherapy followed by RC and LND is likely to remain the gold standard for treatment of MIBC in cisplatin and surgically fit patients, as it allows the best risk stratification [57].

The main limitation of this study is its retrospective design. Due to the differences in staging techniques, tumor subtypes, inclusion criteria and treatment modalities the final cohort analyzed was found to be very heterogeneous. Also, we identified only three studies that thoroughly reported the outcomes after SV-RC, as most studies only briefly mentioned the rates of necessary SV-RC. Despite an acceptable quality of the studies included, prospective trials assessing precisely the risk of SV-RC and the oncologic outcomes are highly needed.

\section{Conclusion}

Approximately one-fifth to one-third of patients treated with BST with a curative intent eventually a SV-RC. This procedure has a proportionally high rate of complications and, while primarily entailing a non-tissue sparing (i.e. nervesparing) approach, usually is accompanied by an incontinent urinary diversion. The resulting decreased quality of life needs to be taken into consideration during the counselling of MIBC patients regarding the risks, benefits and alternatives (i.e. BST) to primary RC.
Acknowledgements Victor Schuettfort is supported by the EUSP scholarship the European Association of Urology.

Author contributions All authors read and approved the final manuscript. VMS: Project development, Data collection + analysis Manuscript writing; BP: Data collection + analysis, Manuscript writing; FQ: Manuscript writing + Data analysis; HM: Manuscript writing + Data analysis; EL: Manuscript writing + Data analysis; KM: Manuscript writing + Data analysis; RSM: Manuscript writing + Data analysis; MF: Manuscript writing + Data analysis; DD: Manuscript writing + Data analysis; MR: Manuscript writing + Data analysis; PG: Manuscript writing + Data analysis; FS: Manuscript writing + Data analysis; SFS: Project development, Data analysis, Manuscript writing.

Funding Open access funding provided by Medical University of Vienna.

Availability of data and material All data and material are available.

\section{Compliance with ethical standards}

Conflict of interest All authors have nothing to disclose.

Open Access This article is licensed under a Creative Commons Attribution 4.0 International License, which permits use, sharing, adaptation, distribution and reproduction in any medium or format, as long as you give appropriate credit to the original author(s) and the source, provide a link to the Creative Commons licence, and indicate if changes were made. The images or other third party material in this article are included in the article's Creative Commons licence, unless indicated otherwise in a credit line to the material. If material is not included in the article's Creative Commons licence and your intended use is not permitted by statutory regulation or exceeds the permitted use, you will need to obtain permission directly from the copyright holder. To view a copy of this licence, visit http://creativecommons.org/licenses/by/4.0/.

\section{References}

1. Vashistha V, Wang H, Mazzone A, Liss MA, Svatek RS, Schleicher M, Kaushik D (2017) Radical cystectomy compared to combined modality treatment for muscle-invasive bladder cancer: a systematic review and meta-analysis. Int J Radiat Oncol Biol Phys 97(5):1002-1020. https://doi.org/10.1016/j.ijrob p.2016.11.056

2. Arcangeli G, Strigari L, Arcangeli S (2015) Radical cystectomy versus organ-sparing trimodality treatment in muscle-invasive bladder cancer: a systematic review of clinical trials. Crit Rev Oncol Hematol 95(3):387-396. https://doi.org/10.1016/j.critr evonc.2015.04.006

3. Kulkarni GS, Hermanns T, Wei Y, Bhindi B, Satkunasivam R, Athanasopoulos P, Bostrom PJ, Kuk C, Li K, Templeton AJ, Sridhar SS, van der Kwast TH, Chung P, Bristow RG, Milosevic M, Warde P, Fleshner NE, Jewett MAS, Bashir S, Zlotta AR (2017) Propensity score analysis of radical cystectomy versus bladder-sparing trimodal therapy in the setting of a multidisciplinary bladder cancer clinic. J Clin Oncol 35(20):2299-2305. https://doi.org/10.1200/JCO.2016.69.2327

4. Mathieu R, Lucca I, Klatte T, Babjuk M, Shariat SF (2015) Trimodal therapy for invasive bladder cancer: is it really equal to radical cystectomy? Curr Opin Urol 25(5):476-482. https://doi. org/10.1097/mou.0000000000000203 
5. Shariat SF, Milowsky M, Droller MJ (2009) Bladder cancer in the elderly. Urol Oncol 27(6):653-667. https://doi.org/10.1016/j. urolonc.2009.07.020

6. Mottet N, Ribal MJ, Boyle H, De Santis M, Caillet P, Choudhury A, Garg T, Nielsen M, Wüthrich P, Gust KM, Shariat SF, Gakis G (2020) Management of bladder cancer in older patients: position paper of a SIOG Task Force. J Geriatr Oncol. https://doi. org/10.1016/j.jgo.2020.02.001

7. Grubmueller B, Seitz C, Shariat SF (2016) The treatment of muscle-invasive bladder cancer in geriatric patients. Curr Opin Urol 26(2):160-164. https://doi.org/10.1097/mou.0000000000 000262

8. Milowsky MI, Rumble RB, Booth CM, Gilligan T, Eapen LJ, Hauke RJ, Boumansour P, Lee CT (2016) Guideline on muscleinvasive and metastatic bladder cancer (European Association of Urology Guideline): American Society of Clinical Oncology Clinical Practice Guideline Endorsement. J Clin Oncol 34(16):1945-1952. https://doi.org/10.1200/jco.2015.65.9797

9. Witjes J, Bruins M, Cathomas R, Compérat R, Cowan N, Gakis G, Hernández V, Lorch A, MJ. R, Thalmann G, van der Heijden A, Veskimäe E (2019) EAU Guidelines on Muscle-invasive and Metastatic Bladder Cancer. EAU Guidelines (2019 Edn)

10. Witjes JA, Babjuk M, Bellmunt J, Bruins HM, De Reijke TM, De Santis M, Gillessen S, James N, Maclennan S, Palou J, Powles T, Ribal MJ, Shariat SF, Der Kwast TV, Xylinas E, Agarwal N, Arends T, Bamias A, Birtle A, Black PC, Bochner BH, Bolla M, Boormans JL, Bossi A, Briganti A, Brummelhuis I, Burger M, Castellano D, Cathomas R, Chiti A, Choudhury A, Compérat E, Crabb S, Culine S, De Bari B, De Blok W, P JLDV, Decaestecker K, Dimitropoulos K, Dominguez-Escrig JL, Fanti S, Fonteyne V, Frydenberg M, Futterer JJ, Gakis G, Geavlete B, Gontero P, Grubmüller B, Hafeez S, Hansel DE, Hartmann A, Hayne D, Henry AM, Hernandez V, Herr H, Herrmann K, Hoskin P, Huguet J, Jereczek-Fossa BA, Jones R, Kamat AM, Khoo V, Kiltie AE, Krege S, Ladoire S, Lara PC, Leliveld A, Linares-Espinós E, Løgager V, Lorch A, Loriot Y, Meijer R, Mir MC, Moschini M, Mostafid H, Müller AC, Müller CR, N'Dow J, Necchi A, Neuzillet Y, Oddens JR, Oldenburg J, Osanto S, W JGO, Pacheco-Figueiredo L, Pappot H, Patel MI, Pieters BR, Plass K, Remzi M, Retz M, Richenberg J, Rink M, Roghmann F, Rosenberg JE, Rouprêt M, Rouvière O, Salembier C, Salminen A, Sargos P, Sengupta S, Sherif A, Smeenk RJ, Smits A, Stenzl A, Thalmann GN, Tombal B, Turkbey B, Lauridsen SV, Valdagni R, Van Der Heijden AG, Van Poppel H, Vartolomei MD, Veskimäe E, Vilaseca A, Rivera FAV, Wiegel T, Wiklund P, Williams A, Zigeuner R, Horwich A, (2020) EAU-ESMO Consensus Statements on the Management of Advanced and Variant Bladder Cancer-An International Collaborative Multistakeholder Effort $(\dagger)$ : Under the Auspices of the EAU-ESMO Guidelines Committees. Eur Urol 77(2):223-250. https://doi.org/10.1016/j. eururo.2019.09.035

11. Huddart RA, Hall E, Lewis R, Birtle A, Group STM (2010) Life and death of spare (selective bladder preservation against radical excision): reflections on why the spare trial closed. BJU Int 106(6):753-755. https://doi.org/10.1111/j.1464410X.2010.09537.x

12. Ploussard G, Daneshmand S, Efstathiou JA, Herr HW, James ND, Rodel CM, Shariat SF, Shipley WU, Sternberg CN, Thalmann GN, Kassouf W (2014) Critical analysis of bladder sparing with trimodal therapy in muscle-invasive bladder cancer: a systematic review. Eur Urol 66(1):120-137. https://doi.org/10.1016/j.eurur o.2014.02.038

13. Huddart RA, Hall E, Lewis R, Porta N, Crundwell M, Jenkins PJ, Rawlings C, Tremlett J, Campani L, Hendron C, Hussain SA, James ND (2020) Patient-reported quality of life outcomes in patients treated for muscle-invasive bladder cancer with radiotherapy \pm chemotherapy in the $\mathrm{BC} 2001$ phase III randomised controlled trial. Eur Urol 77(2):260-268. https://doi. org/10.1016/j.eururo.2019.11.001

14. Rodel C, Grabenbauer GG, Kuhn R, Papadopoulos T, Dunst J, Meyer M, Schrott KM, Sauer R (2002) Combined-modality treatment and selective organ preservation in invasive bladder cancer: long-term results. J Clin Oncol 20(14):3061-3071. https://doi. org/10.1200/JCO.2002.11.027

15. Mak RH, Hunt D, Shipley WU, Efstathiou JA, Tester WJ, Hagan MP, Kaufman DS, Heney NM, Zietman AL (2014) Long-term outcomes in patients with muscle-invasive bladder cancer after selective bladder-preserving combined-modality therapy: a pooled analysis of Radiation Therapy Oncology Group protocols 8802, 8903, 9506, 9706, 9906, and 0233. J Clin Oncol 32(34):3801-3809. https://doi.org/10.1200/JCO.2014.57.5548

16. Hafeez S, Horwich A, Omar O, Mohammed K, Thompson A, Kumar P, Khoo V, Van As N, Eeles R, Dearnaley D, Huddart R (2016) Selective organ preservation with neo-adjuvant chemotherapy for the treatment of muscle invasive transitional cell carcinoma of the bladder. Br J Cancer 114(12):e24. https://doi. org/10.1038/bjc. 2016.132

17. Kim HL, Steinberg GD (2001) Complications of cystectomy in patients with a history of pelvic radiation. Urology 58(4):557560. https://doi.org/10.1016/s0090-4295(01)01269-9

18. Gontero P, Pisano F, Palou J, Joniau S, Albersen M, Colombo R, Briganti A, Pellucchi F, Faba OR, van Rhijn BW, van de Putte EF, Babjuk M, Fritsche HM, Mayr R, Albers P, Niegisch G, Anract J, Masson-Lecomte A, De la Taille A, Roupret M, Peyronnet B, Cai T, Witjes AJ, Bruins M, Baniel J, Mano R, Lapini A, Sessa F, Irani J, Brausi M, Stenzl A, Karnes JR, Scherr D, O'Malley P, Taylor B, Shariat SF, Black P, Abdi H, Matveev VB, Samuseva O, Parekh D, Gonzalgo M, Vetterlein MW, Aziz A, Fisch M, Catto J, Pang KH, Xylinas E, Rink M, Young Academic Urologists Urothelial Carcinoma Group of the European Association of U (2019) Complication rate after cystectomy following pelvic radiotherapy: an international, multicenter, retrospective series of 682 cases. World J Urol. https://doi.org/10.1007/s0034 5-019-02982-6

19. Crawford ED, Skinner DG (1980) Salvage cystectomy after irradiation failure. J Urol 123(1):32-34. https://doi.org/10.1016/ s0022-5347(17)55765-1

20. Smith JA Jr, Whitmore WF Jr (1981) Salvage cystectomy for bladder cancer after failure of definitive irradiation. J Urol 125(5):643-645. https://doi.org/10.1016/s0022-5347(17)55148-4

21. Abratt RP, Wilson JA, Pontin AR, Barnes RD (1993) Salvage cystectomy after radical irradiation for bladder cancer-prognostic factors and complications. Br J Urol 72(5 Pt 2):756-760. https:// doi.org/10.1111/j.1464-410x.1993.tb16262.x

22. Stroup DF, Berlin JA, Morton SC, Olkin I, Williamson GD, Rennie D, Moher D, Becker BJ, Sipe TA, Thacker SB (2000) Metaanalysis of observational studies in epidemiology: a proposal for reporting. Meta-analysis Of Observational Studies in Epidemiology (MOOSE) group. JAMA 283(15):2008-2012. https://doi. org/10.1001/jama.283.15.2008

23. Ploussard G, Daneshmand S, Efstathiou JA, Herr HW, James ND, Rödel CM, Shariat SF, Shipley WU, Sternberg CN, Thalmann GN, Kassouf W (2014) Critical analysis of bladder sparing with trimodal therapy in muscle-invasive bladder cancer: a systematic review. Eur Urol 66(1):120-137. https://doi.org/10.1016/j.eurur o.2014.02.038

24. Slim K, Nini E, Forestier D, Kwiatkowski F, Panis Y, Chipponi J (2003) Methodological index for non-randomized studies (minors): development and validation of a new instrument. ANZ J Surg 73(9):712-716. https://doi.org/10.104 6/j.1445-2197.2003.02748.x 
25. Wang N (2018) How to Conduct a Meta-Analysis of Proportions in R: A Comprehensive Tutorial. https://doi.org/10.13140 /RG.2.2.27199.00161

26. Hunter JP, Saratzis A, Sutton AJ, Boucher RH, Sayers RD, Bown MJ (2014) In meta-analyses of proportion studies, funnel plots were found to be an inaccurate method of assessing publication bias. J Clin Epidemiol 67(8):897-903. https://doi.org/10.1016/j. jclinepi.2014.03.003

27. Peyromaure M, Slama J, Beuzeboc P, Ponvert D, Debré B, Zerbib M (2004) Concurrent chemoradiotherapy for clinical stage T2 bladder cancer: report of a single institution. Urology 63(1):7377. https://doi.org/10.1016/j.urology.2003.09.018

28. Iwai A, Koga F, Fujii Y, Masuda H, Saito K, Numao N, Sakura M, Kawakami S, Kihara K (2011) Perioperative complications of radical cystectomy after induction chemoradiotherapy in bladdersparing protocol against muscle-invasive bladder cancer: a single institutional retrospective comparative study with primary radical cystectomy. Jpn J Clin Oncol 41(12):1373-1379. https://doi. org/10.1093/jjco/hyr150

29. Chahal R, Sundaram SK, Iddenden R, Forman DF, Weston PM, Harrison SC (2003) A study of the morbidity, mortality and long-term survival following radical cystectomy and radical radiotherapy in the treatment of invasive bladder cancer in Yorkshire. Eur Urol 43(3):246-257. https://doi.org/10.1016/ s0302-2838(02)00581-x

30. Eswara JR, Efstathiou JA, Heney NM, Paly J, Kaufman DS, McDougal WS, McGovern F, Shipley WU (2012) Complications and long-term results of salvage cystectomy after failed bladder sparing therapy for muscle invasive bladder cancer. $\mathbf{J}$ Urol 187(2):463-468. https://doi.org/10.1016/j.juro.2011.09.159

31. Cobo M, Delgado R, Gil S, Herruzo I, Baena V, Carabante F, Moreno P, Ruiz JL, Bretón JJ, Del Rosal JM, Fuentes C, Moreno P, García E, Villar E, Contreras J, Alés I, Benavides M (2006) Conservative treatment with transurethral resection, neoadjuvant chemotherapy followed by radiochemotherapy in stage T2-3 transitional bladder cancer. Clin Transl Oncol 8(12):903-911. https://doi.org/10.1007/s12094-006-0154-1

32. Efstathiou JA, Spiegel DY, Shipley WU, Heney NM, Kaufman DS, Niemierko A, Coen JJ, Skowronski RY, Paly JJ, McGovern FJ, Zietman AL (2012) Long-term outcomes of selective bladder preservation by combined-modality therapy for invasive bladder cancer: the MGH experience. Eur Urol 61(4):705-711. https:// doi.org/10.1016/j.eururo.2011.11.010

33. Arias F, Domínguez MA, Martínez E, Illarramendi JJ, Miquelez S, Pascual I, Marcos M (2000) Chemoradiotherapy for muscle invading bladder carcinoma. Final report of a single institutional organ-sparing program. Int J Radiat Oncol Biol Phys 47(2):373378. https://doi.org/10.1016/s0360-3016(00)00444-2

34. Tonoli S, Bertoni F, De Stefani A, Vitali E, De Tomasi D, Caraffini B, Scheda A, Bertocchi M, Somensari A, Buglione M, Magrini SM (2006) Radical radiotherapy for bladder cancer: retrospective analysis of a series of 459 patients treated in an Italian institution. Clin Oncol (R Coll Radiol) 18(1):52-59. https://doi. org/10.1016/j.clon.2005.06.015

35. Giacalone NJ, Shipley WU, Clayman RH, Niemierko A, Drumm M, Heney NM, Michaelson MD, Lee RJ, Saylor PJ, Wszolek MF, Feldman AS, Dahl DM, Zietman AL, Efstathiou JA (2017) Longterm outcomes after bladder-preserving tri-modality therapy for patients with muscle-invasive bladder cancer: an updated analysis of the Massachusetts General Hospital Experience. Eur Urol 71(6):952-960. https://doi.org/10.1016/j.eururo.2016.12.020

36. Kijima T, Tanaka H, Koga F, Masuda H, Yoshida S, Yokoyama M, Ishioka J, Matsuoka Y, Saito K, Kihara K, Fujii Y (2019) Selective tetramodal bladder-preservation therapy, incorporating induction chemoradiotherapy and consolidative partial cystectomy with pelvic lymph node dissection for muscle-invasive bladder cancer: oncological and functional outcomes of 107 patients. BJU Int 124(2):242-250. https://doi.org/10.1111/ bju. 14736

37. Vetterlein MW, Klemm J, Gild P, Bradtke M, Soave A, Dahlem R, Fisch M, Rink M (2020) Improving estimates of perioperative morbidity after radical cystectomy using the European Association of Urology Quality criteria for standardized reporting and introducing the comprehensive complication index. Eur Urol 77(1):55-65. https://doi.org/10.1016/j.eururo.2019.08.011

38. Stein JP, Lieskovsky G, Cote R, Groshen S, Feng AC, Boyd S, Skinner E, Bochner B, Thangathurai D, Mikhail M, Raghavan D, Skinner DG (2001) Radical cystectomy in the treatment of invasive bladder cancer: long-term results in 1054 patients. J Clin Oncol 19(3):666-675. https://doi.org/10.1200/jco.2001.19.3.666

39. Hautmann RE, Gschwend JE, de Petriconi RC, Kron M, Volkmer BG (2006) Cystectomy for transitional cell carcinoma of the bladder: results of a surgery only series in the neobladder era. J Urol 176(2):486-492. https://doi.org/10.1016/j.juro.2006.03.038

40. Isbarn H, Jeldres C, Zini L, Perrotte P, Baillargeon-Gagne S, Capitanio U, Shariat SF, Arjane P, Saad F, McCormack M, Valiquette L, Peloquin F, Duclos A, Montorsi F, Graefen M, Karakiewicz PI (2009) A population based assessment of perioperative mortality after cystectomy for bladder cancer. J Urol 182(1):70-77. https://doi.org/10.1016/j.juro.2009.02.120

41. Aziz A, May M, Burger M, Palisaar RJ, Trinh QD, Fritsche HM, Rink M, Chun F, Martini T, Bolenz C, Mayr R, Pycha A, Nuhn P, Stief C, Novotny V, Wirth M, Seitz C, Noldus J, Gilfrich C, Shariat SF, Brookman-May S, Bastian PJ, Denzinger S, Gierth M, Roghmann F (2014) Prediction of 90-day mortality after radical cystectomy for bladder cancer in a prospective European multicenter cohort. Eur Urol 66(1):156-163. https://doi.org/10.1016/j. eururo.2013.12.018

42. Yang LS, Shan BL, Shan LL, Chin P, Murray S, Ahmadi N, Saxena A (2016) A systematic review and meta-analysis of quality of life outcomes after radical cystectomy for bladder cancer. Surg Oncol 25(3):281-297. https://doi.org/10.1016/j.suron c. 2016.05 .027

43. Zietman AL, Sacco D, Skowronski U, Gomery P, Kaufman DS, Clark JA, Talcott JA, Shipley WU (2003) Organ conservation in invasive bladder cancer by transurethral resection, chemotherapy and radiation: results of a urodynamic and quality of life study on long-term survivors. J Urol 170(5):1772-1776. https://doi. org/10.1097/01.ju.0000093721.23249.c3

44. Zietman AL, Grocela J, Zehr E, Kaufman DS, Young RH, Althausen AF, Heney NM, Shipley WU (2001) Selective bladder conservation using transurethral resection, chemotherapy, and radiation: management and consequences of $\mathrm{Ta}, \mathrm{T} 1$, and $\mathrm{Tis}$ recurrence within the retained bladder. Urology 58(3):380-385. https://doi.org/10.1016/s0090-4295(01)01219-5

45. Pieras E, Palou J, Salvador J, Rosales A, Marcuello E, Villavicencio H (2003) Management and prognosis of transitional cell carcinoma superficial recurrence in muscle-invasive bladder cancer after bladder preservation. Eur Urol 44(2):222-225. https:// doi.org/10.1016/s0302-2838(03)00258-6

46. Williams SB, Shan Y, Ray-Zack MD, Hudgins HK, Jazzar U, Tyler DS, Freedland SJ, Swanson TA, Baillargeon JG, Hu JC, Kaul S, Kamat AM, Gore JL, Mehta HB (2019) Comparison of costs of radical cystectomy vs trimodal therapy for patients with localized muscle-invasive bladder cancer. JAMA Surg 154(8):e191629. https://doi.org/10.1001/jamasurg.2019.1629

47. Choudhury A, Nelson LD, Teo MT, Chilka S, Bhattarai S, Johnston CF, Elliott F, Lowery J, Taylor CF, Churchman M, Bentley J, Knowles MA, Harnden P, Bristow RG, Bishop DT, Kiltie AE (2010) MRE11 expression is predictive of cause-specific survival following radical radiotherapy for muscle-invasive 
bladder cancer. Cancer Res 70(18):7017-7026. https://doi. org/10.1158/0008-5472.Can-10-1202

48. Laurberg JR, Brems-Eskildsen AS, Nordentoft I, Fristrup N, Schepeler T, Ulhøi BP, Agerbaek M, Hartmann A, Bertz S, Wittlinger M, Fietkau R, Rödel C, Borre M, Jensen JB, Orntoft T, Dyrskjøt L (2012) Expression of TIP60 (tat-interactive protein) and MRE11 (meiotic recombination 11 homolog) predict treatment-specific outcome of localised invasive bladder cancer. BJU Int 110(11 Pt C):E1228-E1236. https://doi.org/10.1111/j.1464410X.2012.11564.x

49. Meng W, Efstathiou J, Singh R, McElroy J, Volinia S, Cui R, Ibrahim A, Johnson B, Gupta N, Mehta S, Wang H, Miller E, Nguyen P, Fleming J, Wu CL, Haque SJ, Shipley W, Chakravarti A (2019) MicroRNA biomarkers for patients with muscle-invasive bladder cancer undergoing selective bladder-sparing trimodality treatment. Int J Radiat Oncol Biol Phys 104(1):197-206. https://doi.org/10.1016/j.ijrobp.2018.12.028

50. Sak SC, Harnden P, Johnston CF, Paul AB, Kiltie AE (2005) APE1 and XRCC1 protein expression levels predict cancerspecific survival following radical radiotherapy in bladder cancer. Clin Cancer Res 11(17):6205-6211. https://doi. org/10.1158/1078-0432.Ccr-05-0045

51. del Muro XG, Condom E, Vigués F, Castellsagué X, Figueras A, Muñoz J, Solá J, Soler T, Capellà G, Germà JR (2004) p53 and p21 expression levels predict organ preservation and survival in invasive bladder carcinoma treated with a combined-modality approach. Cancer 100(9):1859-1867. https://doi.org/10.1002/ cncr.20200

52. Efstathiou JA, Mouw KW, Gibb EA, Liu Y, Wu CL, Drumm MR, da Costa JB, du Plessis M, Wang NQ, Davicioni E, Feng FY, Seiler R, Black PC, Shipley WU, Miyamoto DT (2019) Impact of immune and stromal infiltration on outcomes following bladder-sparing trimodality therapy for muscle-invasive bladder cancer. Eur Urol 76(1):59-68. https://doi.org/10.1016/j.eurur o.2019.01.011

53. Koga F, Takemura K, Fukushima H (2018) Biomarkers for predicting clinical outcomes of chemoradiation-based bladder preservation therapy for muscle-invasive bladder cancer. Int J Mol Sci 19(9):78. https://doi.org/10.3390/ijms19092777

54. Pietzak EJ, Sterling ME, Smith ZL, Malkowicz SB, Guzzo TJ (2015) Outcomes of radical cystectomy in potential candidates for bladder preservation therapy. Urology 85(4):869-875. https ://doi.org/10.1016/j.urology.2015.01.001

55. Nieuwenhuijzen JA, Horenblas S, Meinhardt W, van Tinteren H, Moonen LM (2004) Salvage cystectomy after failure of interstitial radiotherapy and external beam radiotherapy for bladder cancer. BJU Int 94(6):793-797. https://doi.org/10.1111/j.1464410X.2004.05034.x

56. Svatek RS, Shariat SF, Novara G, Skinner EC, Fradet Y, Bastian PJ, Kamat AM, Kassouf W, Karakiewicz PI, Fritsche HM, Izawa JI, Tilki D, Ficarra V, Volkmer BG, Isbarn H, Dinney CP (2011) Discrepancy between clinical and pathological stage: external validation of the impact on prognosis in an international radical cystectomy cohort. BJU Int 107(6):898-904. https://doi. org/10.1111/j.1464-410X.2010.09628.X

57. Simone G, Gallucci M (2012) Multimodality treatment versus radical cystectomy: bladder sparing at cost of life? Eur Urol 61(4):712-713. https://doi.org/10.1016/j.eururo.2011.11.051

58. Miyata H, Osawa T, Abe T, Kikuchi H, Matsumoto R, Maruyama S, Nishioka K, Shimizu S, Hashimoto T, Shirato H, Shinohara N (2020) The updated outcomes of bladder-preserving trimodal therapy using a real-time tumor-tracking radiotherapy system for patients with muscle-invasive bladder cancer. Jpn J Clin Oncol. https://doi.org/10.1093/jjco/hyz211

59. Nguyen EK, Yu H, Pond G, Shayegan B, Pinthus JH, Kapoor A, Mukherjee SD, Neville A, Lalani AA, Hotte SJ, Corbett TB,
Dayes IS, Lukka HR (2020) Outcomes of trimodality bladdersparing therapy for muscle-invasive bladder cancer. Can Urol Assoc J 14(4):122-129. https://doi.org/10.5489/cuaj.5945

60. Coen JJ, Zhang P, Saylor PJ, Lee CT, Wu CL, Parker W, Lautenschlaeger T, Zietman AL, Efstathiou JA, Jani AB, Kucuk O, Souhami L, Rodgers JP, Sandler HM, Shipley WU (2019) Bladder preservation with twice-a-day radiation plus fluorouracil/cisplatin or once daily radiation plus gemcitabine for muscle-invasive bladder cancer: NRG/RTOG 0712-a randomized phase II trial. J Clin Oncol 37(1):44-51. https://doi.org/10.1200/JCO.18.00537

61. Murthy V, Gupta P, Baruah K, Krishnatry R, Joshi A, Prabhash K, Noronha V, Menon S, Pal M, Prakash G, Bakshi G (2019) Adaptive radiotherapy for carcinoma of the urinary bladder: longterm outcomes with dose escalation. Clin Oncol (R Coll Radiol) 31(9):646-652. https://doi.org/10.1016/j.clon.2019.06.005

62. Büchser D, Zapatero A, Rogado J, Talaya M, Martín de Vidales C, Arellano R, Bocardo G, Cruz Conde A, Pérez L, Murillo MT (2019) Long-term outcomes and patterns of failure following trimodality treatment with bladder preservation for invasive bladder cancer. Urology 124:183-190. https://doi.org/10.1016/j.urolo gy.2018.07.058

63. Mohamed HAH, Salem MA, Elnaggar MS, Gabr A, Abdelrheem AM (2018) Trimodalities for bladder cancer in elderly: transurethral resection, hypofractionated radiotherapy and gemcitabine. Cancer Radiother 22(3):236-240. https://doi.org/10.1016/j.canra d.2017.09.013

64. Bachir BG, Souhami L, Mansure JJ, Cury F, Vanhuyse M, Brimo F, Aprikian AG, Tanguay S, Sturgeon J, Kassouf W (2017) Phase I clinical trial of everolimus combined with trimodality therapy in patients with muscle-invasive bladder cancer. Bladder Cancer 3(2):105-112. https://doi.org/10.3233/blc-160090

65. Chiang Y, Cheng JC, Huang CY, Tsai YC, Lin CC, Hsu CH, Cheng AL, Pu YS (2017) A role of multimodality bladder-preserving therapy in patients with muscle-invasive bladder cancer plus hydronephrosis with or without pelvic nodal involvement. J Formos Med Assoc 116(9):689-696. https://doi.org/10.1016/j. jfma.2016.10.014

66. Huddart RA, Birtle A, Maynard L, Beresford M, Blazeby J, Donovan J, Kelly JD, Kirkbank T, McLaren DB, Mead G, Moynihan C, Persad R, Scrase C, Lewis R, Hall E (2017) Clinical and patient-reported outcomes of SPARE-a randomised feasibility study of selective bladder preservation versus radical cystectomy. BJU Int 120(5):639-650. https://doi.org/10.1111/ bju. 13900

67. Nagao K, Hara T, Nishijima J, Shimizu K, Fujii N, Kobayashi K, Kawai Y, Inoue R, Yamamoto Y, Matsumoto H, Matsuyama H (2017) The efficacy of trimodal chemoradiotherapy with cisplatin as a bladder-preserving strategy for the treatment of muscle-invasive bladder cancer. Urol Int 99(4):446-452. https ://doi.org/10.1159/000477912

68. Gerardi MA, Jereczek-Fossa BA, Zerini D, Surgo A, Dicuonzo S, Spoto R, Fodor C, Verri E, Rocca MC, Nole F, Muto M, Ferro M, Musi G, Bottero D, Matei DV, De Cobelli O, Orecchia R (2016) Bladder preservation in non-metastatic muscle-invasive bladder cancer (MIBC): a single-institution experience. Ecancermedicalscience 10:657. https://doi.org/10.3332/ecancer.2016.657

69. Rose TL, Deal AM, Ladoire S, Créhange G, Galsky MD, Rosenberg JE, Bellmunt J, Wimalasingham A, Wong YN, Harshman LC, Chowdhury S, Niegisch G, Liontos M, Yu EY, Pal SK, Chen RC, Wang AZ, Nielsen ME, Smith AB, Milowsky MI (2016) Patterns of bladder preservation therapy utilization for muscleinvasive bladder cancer. Bladder Cancer 2(4):405-413. https:// doi.org/10.3233/blc-160072

70. Thompson C, Joseph N, Sanderson B, Logue J, Wylie J, Elliott T, Lyons J, Anandadas C, Choudhury A (2017) Tolerability of concurrent chemoradiation therapy with gemcitabine (GemX), with 
and without prior neoadjuvant chemotherapy, in muscle invasive bladder cancer. Int J Radiat Oncol Biol Phys 97(4):732-739. https://doi.org/10.1016/j.ijrobp.2016.11.040

71. Yoshioka H, Shimbo T, Yoshida K, Yoshikawa N, Uesugi Y, Yamamoto K, Azuma H, Narumi Y (2016) Treatment results of radiotherapy combined with balloon-occluded arterial infusion chemotherapy for invasive bladder cancer. Anticancer Res 36(2):731-736

72. Byun SJ, Kim JH, Oh YK, Kim BH (2015) Concurrent chemoradiotherapy improves survival outcome in muscle-invasive bladder cancer. Radiat Oncol J 33(4):294-300. https://doi. org/10.3857/roj.2015.33.4.294

73. Gofrit ON, Nof R, Meirovitz A, Pode D, Frank S, Katz R, Shapiro A, Landau EH, Hidas G, Yutkin V, Duvdevani M, Wygoda M (2015) Radical cystectomy vs. chemoradiation in T2-4aNOM0 bladder cancer: a case-control study. Urol Oncol 33(1):19. https ://doi.org/10.1016/j.urolonc.2014.09.014

74. Gupta S, De S, Leekha N, Sahay SC, Chaudary P, Srinivasan S, Nandy M (2016) Chemoradiation for organ preservation in the treatment of muscle invasive bladder cancer: our institutional experience. Gulf J Oncol 1(22):55-60

75. Hafeez S, Horwich A, Omar O, Mohammed K, Thompson A, Kumar P, Khoo V, Van As N, Eeles R, Dearnaley D, Huddart R (2015) Selective organ preservation with neo-adjuvant chemotherapy for the treatment of muscle invasive transitional cell carcinoma of the bladder. Br J Cancer 112(10):1626-1635. https:// doi.org/10.1038/bjc.2015.109

76. Nowak-Sadzikowska J, Skóra T, Szyszka-Charewicz B, Jakubowicz J (2016) Muscle-invasive bladder cancer treated with TURB followed by concomitant boost with small reduction of radiotherapy field with or without of chemotherapy. Rep Pract Oncol Radiother 21(1):31-36. https://doi.org/10.1016/j. rpor.2015.09.001

77. Roy C, Choudhury K, Ghosh A, Saha A, Joarder R, Akhil S (2015) Feasibility of organ preservation in muscle-invasive transitional cell carcinoma bladder: a single institutional approach. Clin Cancer Investig J 4:175

78. Whalley D, Caine H, McCloud P, Guo L, Kneebone A, Eade T (2015) Promising results with image guided intensity modulated radiotherapy for muscle invasive bladder cancer. Radiat Oncol 10:205. https://doi.org/10.1186/s13014-015-0499-0

79. Azria D, Riou O, Rebillard X, Thezenas S, Thuret R, Fenoglietto P, Pouessel D, Culine S (2014) Combined chemoradiation therapy with twice-weekly gemcitabine and cisplatin for organ preservation in muscle-invasive bladder cancer: long-term results of a phase 1 trial. Int J Radiat Oncol Biol Phys 88(4):853-859. https ://doi.org/10.1016/j.ijrobp.2013.11.016

80. Lee CY, Yang KL, Ko HL, Huang RY, Tsai PP, Chen MT, Lin YC, Hwang TI, Juang GD, Chi KH (2014) Trimodality bladder-sparing approach without neoadjuvant chemotherapy for node-negative localized muscle-invasive urinary bladder cancer resulted in comparable cystectomy-free survival. Radiat Oncol 9:213. https://doi.org/10.1186/1748-717x-9-213

81. Huddart RA, Hall E, Hussain SA, Jenkins P, Rawlings C, Tremlett J, Crundwell M, Adab FA, Sheehan D, Syndikus I, Hendron C, Lewis R, Waters R, James ND (2013) Randomized noninferiority trial of reduced high-dose volume versus standard volume radiation therapy for muscle-invasive bladder cancer: results of the BC2001 trial (CRUK/01/004). Int J Radiat Oncol Biol Phys 87(2):261-269. https://doi.org/10.1016/j.ijrobp.2013.06.2044

82. Panteliadou M, Giatromanolaki A, Touloupidis S, Destouni E, Tsoutsou PG, Pantelis P, Abatzoglou I, Sismanidou K, Koukourakis MI (2012) Treatment of invasive bladder cancer with conformal hypofractionated accelerated radiotherapy and amifostine (HypoARC). Urol Oncol 30(6):813-820. https://doi. org/10.1016/j.urolonc.2010.09.001
83. Zapatero A, Martin De Vidales C, Arellano R, Ibañez Y, Bocardo G, Perez M, Rabadan M, García Vicente F, Cruz Conde JA, Olivier C (2012) Long-term results of two prospective bladdersparing trimodality approaches for invasive bladder cancer: neoadjuvant chemotherapy and concurrent radio-chemotherapy. Urology 80(5):1056-1062. https://doi.org/10.1016/j.urolo gy.2012.07.045

84. Choudhury A, Swindell R, Logue JP, Elliott PA, Livsey JE, Wise M, Symonds P, Wylie JP, Ramani V, Sangar V, Lyons J, Bottomley I, McCaul D, Clarke NW, Kiltie AE, Cowan RA (2011) Phase II study of conformal hypofractionated radiotherapy with concurrent gemcitabine in muscle-invasive bladder cancer. J Clin Oncol 29(6):733-738. https://doi.org/10.1200/JCO.2010.31.5721

85. Krause FS, Walter B, Ott OJ, Häberle L, Weiss C, Rödel C, Wullich B, Sauer R (2011) 15-Year survival rates after transurethral resection and radiochemotherapy or radiation in bladder cancer treatment. Anticancer Res 31(3):985-990

86. Maarouf AM, Khalil S, Salem EA, ElAdl M, Nawar N, Zaiton F (2011) Bladder preservation multimodality therapy as an alternative to radical cystectomy for treatment of muscle invasive bladder cancer. BJU Int 107(10):1605-1610. https://doi. org/10.1111/j.1464-410X.2010.09564.X

87. Tunio MA, Hashmi A, Qayyum A, Mohsin R, Zaeem A (2012) Whole-pelvis or bladder-only chemoradiation for lymph nodenegative invasive bladder cancer: single-institution experience. Int J Radiat Oncol Biol Phys 82(3):e457-e462. https://doi. org/10.1016/j.ijrobp.2011.05.051

88. Hoskin PJ, Rojas AM, Bentzen SM, Saunders MI (2010) Radiotherapy with concurrent carbogen and nicotinamide in bladder carcinoma. J Clin Oncol 28(33):4912-4918. https:// doi.org/10.1200/jco.2010.28.4950

89. Lagrange JL, Bascoul-Mollevi C, Geoffrois L, Beckendorf V, Ferrero JM, Joly F, Allouache N, Bachaud JM, Chevreau C, Kramar A, Chauvet B (2011) Quality of life assessment after concurrent chemoradiation for invasive bladder cancer: results of a multicenter prospective study (GETUG 97-015). Int J Radiat Oncol Biol Phys 79(1):172-178. https://doi. org/10.1016/j.ijrobp.2009.10.038

90. Aboziada MA, Hamza HM, Abdlrahem AM (2009) Initial results of bladder preserving approach by chemo-radiotherapy in patients with muscle invading transitional cell carcinoma. J Egypt Natl Cancer Inst 21(2):167-174

91. Lin CC, Hsu CH, Cheng JC, Huang CY, Tsai YC, Hsu FM, Huang KH, Cheng AL, Pu YS (2009) Induction cisplatin and fluorouracil-based chemotherapy followed by concurrent chemoradiation for muscle-invasive bladder cancer. Int J Radiat Oncol Biol Phys 75(2):442-448. https://doi.org/10.1016/j.ijrob p.2008.11.030

92. Ikushima H, Iwamoto S, Osaki K, Furutani S, Yamashita K, Kawanaka T, Kubo A, Takegawa Y, Kudoh T, Kanayama H, Nishitani H (2008) Effective bladder preservation strategy with low-dose radiation therapy and concurrent intraarterial chemotherapy for muscle-invasive bladder cancer. Radiat Med 26(3):156-163. https://doi.org/10.1007/s11604-007-0211-x

93. Kotwal S, Choudhury A, Johnston C, Paul AB, Whelan P, Kiltie AE (2008) Similar treatment outcomes for radical cystectomy and radical radiotherapy in invasive bladder cancer treated at a United Kingdom specialist treatment center. Int J Radiat Oncol Biol Phys 70(2):456-463. https://doi.org/10.1016/j.ijrob p.2007.06.030

94. Oh KS, Soto DE, Smith DC, Montie JE, Lee CT, Sandler HM (2009) Combined-modality therapy with gemcitabine and radiation therapy as a bladder preservation strategy: longterm results of a phase I trial. Int J Radiat Oncol Biol Phys 74(2):511-517. https://doi.org/10.1016/j.ijrobp.2008.08.021 
95. Sabaa MA, El-Gamal OM, Abo-Elenen M, Khanam A (2010) Combined modality treatment with bladder preservation for muscle invasive bladder cancer. Urol Oncol 28(1):14-20. https ://doi.org/10.1016/j.urolonc.2008.07.005

96. Yadav BS, Ghoshal S, Sharma SC (2008) Outcome following radical cystectomy and bladder-preservation therapy in patients with invasive carcinoma of urinary bladder. Indian $\mathbf{J}$ Urol 24(1):48-53. https://doi.org/10.4103/0970-1591.38603

97. Chung PW, Bristow RG, Milosevic MF, Yi QL, Jewett MA, Warde PR, Catton CN, McLean M, Moore M, Tannock IF, Gospodarowicz MK (2007) Long-term outcome of radiation-based conservation therapy for invasive bladder cancer. Urol Oncol 25(4):303-309. https://doi.org/10.1016/j.urolo nc.2006.09.015

98. Gamal El-Deen HS (2007) Initial results of retrospective study: preoperative transurethral excision plus chemotherapy and radiation therapy and trial of bladder preservation. J Egypt Natl Cancer Inst 19(2):133-146

99. Müller AC, Diestelhorst A, Kuhnt T, Kühn R, Fornara P, Scholz HJ, Dunst J, Zietman AL (2007) Organ-sparing treatment of advanced bladder cancer: paclitaxel as a radiosensitizer. Strahlenther Onkol 183(4):177-183. https://doi.org/10.1007/s0006 6-007-1651-z

100. Perdonà S, Autorino R, Damiano R, De Sio M, Morrica B, Gallo L, Silvestro G, Farella A, De Placido S, Di Lorenzo G (2008) Bladder-sparing, combined-modality approach for muscle-invasive bladder cancer: a multi-institutional, long-term experience. Cancer 112(1):75-83. https://doi.org/10.1002/cncr.23137

101. Gogna NK, Matthews JH, Turner SL, Mameghan H, Duchesne GM, Spry N, Berry MP, Keller J, Tripcony L (2006) Efficacy and tolerability of concurrent weekly low dose cisplatin during radiation treatment of localised muscle invasive bladder transitional cell carcinoma: a report of two sequential phase II studies from the Trans Tasman Radiation Oncology Group. Radiother Oncol 81(1):9-17. https://doi.org/10.1016/j.radonc.2006.09.001

102. Hata M, Miyanaga N, Tokuuye K, Saida Y, Ohara K, Sugahara S, Kagei K, Igaki H, Hashimoto T, Hattori K, Shimazui T, Akaza H, Akine Y (2006) Proton beam therapy for invasive bladder cancer: a prospective study of bladder-preserving therapy with combined radiotherapy and intra-arterial chemotherapy. Int J Radiat Oncol Biol Phys 64(5):1371-1379. https://doi.org/10.1016/j.jirob p.2005.10.023

103. Kragelj B, Zaletel-Kragelj L, Sedmak B, Cufer T, Cervek J (2005) Phase II study of radiochemotherapy with vinblastine in invasive bladder cancer. Radiother Oncol 75(1):44-47. https:// doi.org/10.1016/j.radonc.2005.01.007

104. Sangar VK, McBain CA, Lyons J, Ramani VA, Logue JP, Wylie JP, Clarke NW, Cowan RA (2005) Phase I study of conformal radiotherapy with concurrent gemcitabine in locally advanced bladder cancer. Int J Radiat Oncol Biol Phys 61(2):420-425. https://doi.org/10.1016/j.ijrobp.2004.05.074

105. Cowan RA, McBain CA, Ryder WD, Wylie JP, Logue JP, Turner SL, Van der Voet J, Collins CD, Khoo VS, Read GR (2004) Radiotherapy for muscle-invasive carcinoma of the bladder: results of a randomized trial comparing conventional whole bladder with dose-escalated partial bladder radiotherapy. Int J Radiat Oncol Biol Phys 59(1):197-207. https://doi.org/10.1016/j.ijrob p.2003.10.018

106. Danesi DT, Arcangeli G, Cruciani E, Altavista P, Mecozzi A, Saracino B, Orefici F (2004) Conservative treatment of invasive bladder carcinoma by transurethral resection, protracted intravenous infusion chemotherapy, and hyperfractionated radiotherapy: long term results. Cancer 101(11):2540-2548. https://doi. org/10.1002/cncr.20654

107. Eapen L, Stewart D, Collins J, Peterson R (2004) Effective bladder sparing therapy with intra-arterial cisplatin and radiotherapy for localized bladder cancer. J Urol 172(4 Pt 1):1276-1280. https ://doi.org/10.1097/01.ju.0000140456.42509.b6

108. George L, Bladou F, Bardou VJ, Gravis G, Tallet A, Alzieu C, Serment G, Salem N (2004) Clinical outcome in patients with locally advanced bladder carcinoma treated with conservative multimodality therapy. Urology 64(3):488-493. https://doi. org/10.1016/j.urology.2004.04.088

109. Horwich A, Dearnaley D, Huddart R, Graham J, Bessell E, Mason M, Bliss J (2005) A randomised trial of accelerated radiotherapy for localised invasive bladder cancer. Radiother Oncol 75(1):34-43. https://doi.org/10.1016/j.radonc.2004.11.003

110. Hussain SA, Stocken DD, Peake DR, Glaholm JG, Zarkar A, Wallace DM, James ND (2004) Long-term results of a phase II study of synchronous chemoradiotherapy in advanced muscle invasive bladder cancer. Br J Cancer 90(11):2106-2111. https:// doi.org/10.1038/sj.bjc.6601852

111. Kent E, Sandler H, Montie J, Lee C, Herman J, Esper P, Fardig J, Smith DC (2004) Combined-modality therapy with gemcitabine and radiotherapy as a bladder preservation strategy: results of a phase I trial. J Clin Oncol 22(13):2540-2545. https://doi. org/10.1200/jco.2004.10.070

112. Caffo O, Fellin G, Graffer U, Valduga F, Bolner A, Luciani L, Tomio L, Galligioni E (2003) Phase I study of gemcitabine and radiotherapy plus cisplatin after transurethral resection as conservative treatment for infiltrating bladder cancer. Int J Radiat Oncol Biol Phys 57(5):1310-1316. https://doi.org/10.1016/s0360 -3016(03)00763-6

113. Yavuz AA, Yavuz MN, Ozgur GK, Colak F, Ozyavuz R, Cimsitoglu E, Ilis E (2003) Accelerated super fractionated radiotherapy with concomitant boost for invasive bladder cancer. Int J Radiat Oncol Biol Phys 56(3):734-745. https://doi.org/10.1016/s0360 -3016(03)00111-1

114. Borgaonkar S, Jain A, Bollina P, McLaren DB, Tulloch D, Kerr GR, Howard GC (2002) Radical radiotherapy and salvage cystectomy as the primary management of transitional cell carcinoma of the bladder. Results following the introduction of a CT planning technique. Clin Oncol (R Coll Radiol) 14(2):141-147. https ://doi.org/10.1053/clon.2002.0055

115. Shipley WU, Kaufman DS, Zehr E, Heney NM, Lane SC, Thakral HK, Althausen AF, Zietman AL (2002) Selective bladder preservation by combined modality protocol treatment: long-term outcomes of 190 patients with invasive bladder cancer. Urology 60(1):62-67. https://doi.org/10.1016/s0090-4295(02)01650-3

116. Scrimger RA, Murtha AD, Parliament MB, Venner PM, Hanson J, Houle G, Chetner M (2001) Muscle-invasive transitional cell carcinoma of the urinary bladder: a population-based study of patterns of care and prognostic factors. Int J Radiat Oncol Biol Phys 51(1):23-30. https://doi.org/10.1016/s0360-3016(01)01591 $-7$

117. Cooke PW, Dunn JA, Latief T, Bathers S, James ND, Wallace DM (2000) Long-term risk of salvage cystectomy after radiotherapy for muscle-invasive bladder cancer. Eur Urol 38(3):279-286. https://doi.org/10.1159/000020294

118. Miyanaga N, Akaza H, Okumura T, Sekido N, Kawai K, Shimazui T, Kikuchi K, Uchida K, Takeshima H, Ohara K, Akine Y, Ita Y (2000) A bladder preservation regimen using intra-arterial chemotherapy and radiotherapy for invasive bladder cancer: a prospective study. Int J Urol 7(2):41-48. https://doi.org/10.104 6/j.1442-2042.2000.00137.x

Publisher's Note Springer Nature remains neutral with regard to jurisdictional claims in published maps and institutional affiliations. 


\section{Affiliations}

Victor M. Schuettfort ${ }^{1,2}$ (D) Benjamin Pradere ${ }^{1,3} \cdot$ Fahad Quhal $^{1,4} \cdot$ Hadi Mostafaei $^{1,5} \cdot$ Ekaterina Laukhtina $^{1,6}$. Keiichiro Mori ${ }^{1,7} \cdot$ Reza Sari Motlagh $^{1} \cdot$ Margit Fisch $^{2} \cdot$ David D'Andrea $^{1} \cdot$ Michael Rink $^{2}$ - Paolo Gontero ${ }^{8}$.

Francesco Soria ${ }^{8} \cdot$ Shahrokh F. Shariat ${ }^{1,6,9,10,11,12}$

1 Department of Urology, Comprehensive Cancer Center, Vienna General Hospital, Medical University of Vienna, Währinger Gürtel 18-20, 1090 Vienna, Austria

2 Department of Urology, University Medical Center Hamburg-Eppendorf, Hamburg, Germany

3 Department of Urology, University Hospital of Tours, Tours, France

4 Department of Urology, King Fahad Specialist Hospital, Dammam, Saudi Arabia

5 Research Center for Evidence Based Medicine, Tabriz University of Medical Sciences, Tabriz, Iran

6 Institute for Urology and Reproductive Health, Sechenov University, Moscow, Russia
7 Department of Urology, The Jikei University School of Medicine, Tokyo, Japan

8 Division of Urology, Department of Surgical Sciences, San Giovanni Battista Hospital, University of Studies of Torino, Turin, Italy

9 Department of Urology, Weill Cornell Medical College, New York, NY, USA

10 Department of Urology, University of Texas Southwestern, Dallas, TX, USA

11 Karl Landsteiner Institute of Urology and Andrology, Vienna, Austria

12 European Association of Urology Research Foundation, Arnhem, The Netherlands 